\title{
ANALISIS TINGKAT KEPUASAN PELANGGAN TERHADAP KUALITAS PELAYANAN JASA PADA SPA ISTANA PERMATA NGESONG SURABAYA
}

\author{
${ }^{1)}$ Maria Fransiska Tien Kewuta \\ ${ }^{2)}$ Edy Sulistiyawan. S.Si., M.Si \\ ${ }^{1)}$ S1 Program Statistika, FMIPA, Universitas PGRI Adi Buana Surabaya \\ ${ }^{2)}$ Program Studi Statistika, FMIPA, Universitas PGRI Adi Buana Surabaya
}

\begin{abstract}
ABSTRAK
Bisnis yang saat ini tengah mengalami perkembangan adalah bisnis jasa dibidang Spa. Jasa layanan di spa tidak berbentuk produk fisik melainkan lebih kepada kinerja yang hanya dapat dinilai setelah jasa atau layanan disampaikan kepada pelanggan. Tujuan dari penelitian ini adalah untuk mengetahui ada atau tidaknya pengaruh yang signifikan dari faktor kualitas pelayanan jasa terhadap kepuasan pelanggan secara serempak dan parsial, serta mengetahui faktor kualitas pelayanan jasa yang paling dominan berpengaruh terhadap kepuasan pelanggan di di Spa Istana Permata Ngesong, Surabaya. Data yang digunakan adalah data primer melalui kuesioner yang disebarkan langsung kepada pelanggan Spa Istana Permata Ngesong, Surabaya. Sampel yang digunakan dalam penelitian ini berjumlah 60 orang. Model pengolahan data yang digunakan untuk menganalisis data adalah Regresi Linier Berganda menggunakan bantuan perangkat lunak SPSS for Windows 16 dengan taraf signifikansi 0.05. Dalam mengambil keputusan dilakukan dengan uji $\mathrm{F}$ dan uji t serta analisis regresi dengan metode Backward untuk mengetahui faktor kualitas pelayanan jasa yang dominan berpengaruh terhadap kepuasan pelanggan di Spa Istana Permata Ngesong, Surabaya. Hasil dari penelitian ini menunjukkan bahwa berdasarkan uji F, variabel Tangible, Reliability, Responsiveness, Assurance dan Empathy berpengaruh signifikan terhadap keputusan pembelian dengan signifikansi 0,000 $(<0,05)$. Dalam uji t untuk variabel Reliability dan Responsiveness, didapatkan hasil bahwa kedua variabel tersebut tidak berpengaruh terhadap variabel Customer Satisfaction dengan signifikansi lebih besar dari 0,05 (>0,05), sedangkan untuk variabel Tangible, Assurance dan Empathy didapatkan hasil bahwa ketiga variabel tersebut berpengaruh terhadap variabel Customer Satisfaction dengan signifikansi lebih kecil dari 0,05 $(<0,05)$. Pada pengujian dengan metode Backward, diperoleh hasil faktor yang dominan berpengaruh terhadap Customer Satisfaction adalah Tangible, Assurance dan Empathy. Sedangkan pengujian dengan menggunakan metode Backward menunjukkan bahwa variabel Tangible, Assurance dan Empathy merupakan variabel yang dominan berpengaruh terhadap Customer Satisfaction.
\end{abstract}

Kata Kunci : tangible, reliability, responsiveness, assurance, empathy, customer satisfaction. 


\section{Pendahuluan}

Bagi setiap perusahaan jasa Spa, perlu berupaya memberikan yang terbaik kepada pelanggannya. Untuk itu perlu dilakukan riset untuk mengidentifikasi faktor kualitas pelayanan jasa yang paling penting bagi pasar sasaran dan memperkirakan penilaian yang diberikan pasar sasaran terhadap perusahaan dan pesaing terutama tentang pertimbangan tingkat kepuasan pelanggan. Dengan menganalisa tanggapan pelanggan terhadap variabel-variabel tersebut maka perusahaan jasa ini dapat menilai variabel mana yang paling dominan berpengaruh terhadap kepuasan pelanggan.

Kepuasan pelanggan akan terpenuhi apabila proses penyampaian jasa dari pemberi jasa kepada pelanggan sesuai dengan apa yang dipersepsikan konsumen. Berbagai faktor seperti Tangible (bukti fisik), Reliability (kesigapan), Responsiveness (kesigapan), Assurance (jaminan) dan Empathy (kepedulian), tidak jarang turut mempengaruhi sehingga jasa sering disampaikan dengan cara yang berbeda dengan yang dipersepsikan oleh konsumen. Pada penelitian ini kami ingin mengetahui pengaruh faktor-faktor kualitas pelayanan jasa terhadap kepuasan pelanggan secara serempak maupun parsial, juga ingin mengetahui faktor yang dominan berpengaruh terhadap kepuasan pelanggan.

\section{Analisis Regresi Linier Berganda}

Analisis regresi linier berganda digunakan oleh peneliti, bila peneliti bermaksud meramalkan bagaimana keadaan (naik turunnya) variabel dependen, bila dua atau lebih variabel independen sebagai faktor prediktor dimanipulasi (dinaikturunkan nilainya). Jadi, analisis regresi berganda akan dilakukan bila jumlah variabel independennya minimal 2 atau lebih.

Secara umum, data hasil pengamatan $\mathrm{Y}$ dipengaruhi oleh variabel-variabel independen $\mathrm{X}_{1}, \mathrm{X}_{2}, \mathrm{X}_{3}, \ldots, \mathrm{X}_{\mathrm{n} .}$ Jadi, rumus umum dari regresi berganda adalah:

$$
Y=\beta_{0}+\beta_{1} X_{1}+\beta_{2} X_{2}+\cdots+\beta_{n} X_{n}+\varepsilon
$$

Dimana :

$\mathrm{Y}=$ Variabel dependen

$\mathrm{X}_{1}, \mathrm{X}_{2}, \ldots, \mathrm{X}_{\mathrm{n}}=$ Variabel independen

$\beta_{0} \quad=$ Konstanta

$\beta_{1}, \beta_{2}, \ldots, \beta_{n}=$ Parameter regresi

$\varepsilon \quad \quad=$ Variabel lain yang tidak diteliti / dimasukkan dalam model

\section{Materi Dan Metode Penelitian}

Metode yang digunakan dalam penelitian ini yaitu dengan cara penyebaran kuesioner. Penyebaran kuesioner dilakukan dalam dua tahap yaitu melalui survey pendahuluan dan selanjutnya survey secara keseluruhan pada bulan Juli 2013 kepada pelanggan Spa Istana Permata Ngesong, Surabaya yang berusia diatas 17 tahun dan telah berkunjung minimal tiga kali dalam sebulan terakhir. 


\subsection{Variabel dan Defenisi Operasional Variabel}

Dalam penelitian ini terdapat enam variabel yang akan diteliti, yaitu 5 variabel independen dan satu variabel dependen variabel tangible (bukti fisik), reliability (keandalan), responsiveness (kesigapan), assurance (jaminan), dan empathy (kepedulian/perhatian) yang merupakan variabel bebas (independen variabel), sedangkan kepuasan pelanggan merupakan variabel terikat (dependen variabel). Selain itu, juga ada dua variabel deskriptif yang akan dibahas yaitu variabel karakteristik responden dan variabel perilaku responden.

\subsection{Langkah-Langkah Analisis Data}

Teknik pengumpulan data yang digunakan dalam penelitian ini adalah kuesioner, yaitu dengan membuat daftar pertanyaan yang berkaitan dengan variabel independen dan variabel dependen. Dengan rincian variabel independen terdiri dari 15 pernyataan dan variabel dependen terdiri dari 3 pernyataan.

Penelitian ini akan menggunakan pengukuran interval dengan skala likert atau skala pengukuran numerik 1-5 (skala 1 sangat tidak puas sampai skala 5 sangat puas).

Model pengolahan data yang digunakan untuk menganalisis data adalah Multiple Linear (regresi linier berganda) dengan menggunakan aplikasi progam computer atau software Statistical Product and Service Solution (SPSS 16) for Windows.

\section{Hasil Penelitian dan Pembahasan}

Analisis regresi berganda dalam penelitian ini dimaksudkan untuk mengetahui pola dan mengukur perubahan pengaruh faktor tangible, reliability, responsiveness, assurance dan empathy terhadap customer satisfaction di Spa Istana Permata Ngesong, Surabaya.

Tabel 4.1 : Hasil Uji Regresi Berganda

\begin{tabular}{|l|c|c|c|}
\hline Variabel & Koefisien Regresi & Sig. & t hitung \\
\hline Konstanta & $-0,177$ & 0,773 & $-0,290$ \\
\hline Faktor Tangible (X1) & 0,252 & 0,034 & 2,175 \\
\hline Faktor Reliability (X2) & 0,049 & 0,734 & 0,342 \\
\hline Faktor Responsiveness (X3) & 0,021 & 0,915 & 0,108 \\
\hline Faktor Assurance (X4) & 0,540 & 0,002 & 3,232 \\
\hline Faktor Empathy (X5) & 0,229 & 0,034 & 2,175 \\
\hline \multicolumn{3}{|c|}{$\mathrm{R}^{2}=0,683$} \\
$\mathrm{R}=0,467$ & $\mathrm{Sig}=0,000$ \\
$\mathrm{~F}=9,447$ \\
\hline
\end{tabular}

Dari data tersebut, maka dihasilkan persamaan regresi sebagai berikut: $Y=\beta_{0}+\beta_{1} X_{1}+\beta_{2} X_{2}+\beta_{3} X_{3}+\beta_{4} X_{4}+\beta_{5} X_{5}+\varepsilon$ $Y=-0,177+0,252 X_{1}+0,049 X_{2}+0,021 X_{3}+0,540 X_{4}+0,229 X_{5}$ 
18) Analisis Tingkat Kepuasan Pelanggan Terhadap Kualitas Pelayanan Jasa Pada Spa Istana Permata Ngesong Surabaya

\section{Uji F (Uji Serentak)}

Tabel 4.2 : Hasil Uji F (Anova)

\begin{tabular}{|ll|r|r|r|r|r|}
\hline Model & Sum of Squares & \multicolumn{1}{c|}{ df } & Mean Square & F & Sig. \\
\hline 1 Regression & 8.346 & 5 & 1.669 & 9.447 & .000 \\
& Residual & 9.541 & 54 & .177 & & \\
& Total & 17.887 & 59 & & & \\
\hline
\end{tabular}

Berdasarkan hasil uji ANOVA atau uji $\mathrm{F}$ pada tabel 4.2, didapatkan $\mathrm{F}_{\text {hitung }}$ sebesar 9.447 dengan tingkat signifikansi 0.000 . Perbandingan antara nilai $F_{\text {hitung }}$ dengan $F_{\text {tabel }}$ yaitu $9.447>2.37$. Berdasarkan kriteria pengujian hipotesis jika $F_{\text {hitung }}>$ $\mathrm{F}_{\text {tabel }}$ maka $\mathrm{H}_{0}$ ditolak, artinya variabel independen (tangible, reliability, responsiveness, assurance, empathy) mempengaruhi variabel dependen (customer satisfaction) secara simultan atau bersama-sama. Selain itu, nilai signifikansi dibawah 0,05 menunjukkan bahwa variabel independen berpengaruh terhadap variabel dependen, ditunjukkan dengan nilai signifikansi sebesar 0,000. Hal ini berarti variabel tangible, reliability, responsiveness, assurance dan empathy efektif apabila digunakan secara simultan atau bersama-sama dalam melakukan penilaian terhadap customer satisfaction.

\section{Uji t (Uji Parsial)}

Dari tabel 10 dapat kita lihat hasil uji t pada kolom t. Dengan mengacu pada tabel dapat kita peroleh $t_{\text {tabel }}$ sebesar 2,00.

Tabel 4.3 Hasil Uji t

\begin{tabular}{|l|r|r|r|r|r|}
\hline \multirow{2}{*}{ Model } & \multicolumn{2}{|c|}{ Unstandardized Coefficients } & \multicolumn{1}{c|}{$\begin{array}{c}\text { Standardized } \\
\text { Coefficients }\end{array}$} & \\
\cline { 2 - 6 } & \multicolumn{1}{|c|}{$\mathrm{B}$} & \multicolumn{1}{|c|}{ Std. Error } & \multicolumn{1}{c|}{ Beta } & \multicolumn{1}{c|}{ Sig. } \\
\hline 1(Constant) & -.177 & .610 & & -.290 & .773 \\
Tangible & .252 & .116 & .243 & 2.175 & .034 \\
Reliability & .049 & .145 & .044 & .342 & .734 \\
Responsiveness & .021 & .196 & .014 & .108 & .915 \\
Assurance & .540 & .167 & .434 & 3.232 & .002 \\
Empathy & .229 & .105 & .237 & 2.175 & .034 \\
\hline
\end{tabular}

\section{Model Terbaik}

Setelah dilakukan analisis regresi berganda, uji serempak (uji F) dan uji parsial (uji t), dilakukan pula analisis untuk mengetahui faktor-faktor kualitas pelayanan jasa yang paling dominan berpengaruh terhadap kepuasan pelanggan. Pengujian untuk menentukan model terbaik dilakukan menggunakan analisis dengan metode Backward. 
Tabel 4.4 : Hasil Estimasi Regresi Linier Berganda

\begin{tabular}{|c|c|c|c|c|c|c|}
\hline \multirow{2}{*}{\multicolumn{2}{|c|}{ Model }} & \multicolumn{2}{|c|}{ Unstandardized Coefficients } & \multirow{2}{*}{$\begin{array}{c}\text { Standardized } \\
\text { Coefficients }\end{array}$} & \multirow[b]{2}{*}{$\mathrm{t}$} & \multirow[b]{2}{*}{ Sig. } \\
\hline & & $\mathrm{B}$ & Std. Error & & & \\
\hline \multirow[t]{6}{*}{1} & (Constant) & -.177 & .610 & & -.290 & .773 \\
\hline & Tangible & .252 & .116 & .243 & 2.175 & .034 \\
\hline & Reliability & .049 & .145 & .044 & .342 & .734 \\
\hline & Responsiveness & .021 & .196 & .014 & .108 & .915 \\
\hline & Assurance & .540 & .167 & .434 & 3.232 & .002 \\
\hline & Empathy & .229 & .105 & .237 & 2.175 & .034 \\
\hline \multirow[t]{5}{*}{2} & (Constant) & -.151 & .556 & & -.272 & .787 \\
\hline & Tangible & .251 & .115 & .243 & 2.192 & .033 \\
\hline & Reliability & .052 & .142 & .047 & .365 & .716 \\
\hline & Assurance & .547 & .150 & .440 & 3.649 & .001 \\
\hline & Empathy & .232 & .100 & .240 & 2.314 & .024 \\
\hline \multirow[t]{4}{*}{3} & (Constant) & -.118 & .544 & & -.216 & .830 \\
\hline & Tangible & .268 & .105 & .259 & 2.559 & .013 \\
\hline & Assurance & .576 & .127 & .463 & 4.528 & .000 \\
\hline & Empathy & .229 & .099 & .237 & 2.311 & .025 \\
\hline
\end{tabular}

a. Dependent Variable: Customer_Satisfaction

Berdasarkan tabel 4.4, pada model 1, P-value yang signifikan $(<0,5)$ terdapat pada variabel Tangible, Assurance dan Empathy, nilai P-value yang paling besar tidak signifikan akan dikeluarkan dari model yaitu variabel Responsiveness. Model 2 tanpa menggunakan variabel Responsiveness, menunjukkan nilai P-value yang tidak signifikan terdapat pada variabel Reliability, sehingga dikeluarkan dari model. Pada model 3, diperoleh nilai P-value dari variabel Tangible, Assurance dan Empathy sudah signifikan sehingga tidak ada variabel yang perlu dikeluarkan dari model dan variabel yang dipilih atau digunakan dalam model yaitu variabel Tangible, Assurance dan Empathy. Dengan demikian, diperoleh model terbaik seperti dibawah ini :

$Y=\beta_{0}+\beta_{1} X_{1}+\beta_{4} X_{4}+\beta_{5} X_{5}+\varepsilon$

$Y=-0,118+0,268 X_{1}+0,576 X_{4}+0,229 X_{5}$

\section{SIMPULAN}

Dari hasil penelitian dan pembahasan sebelumnya, maka dapat ditarik kesimpulan sebagai berikut:

Hasil pengujian hipotesis secara serentak (uji F) variabel independen (Tangible/bukti fisik, Reliability/keandalan, Responsiveness/kesigapan, Assurance/jaminan, dan Empathy/kepedulian) berpengaruh secara signifikan terhadap variabel dependen (Customer Satisfaction/kepuasan pelanggan) Spa Istana Permata Ngesong, Surabaya. Dengan demikian kesimpulannya tolak $\mathrm{H}_{0}$, terima $\mathrm{H}_{1}$, yaitu ada 
pengaruh variabel independen terhadap variabel dependen secara bersama-sama atau serentak. Hasil pengujian hipotesis secara parsial (uji t), ada dua variabel independen (Reliability/keandalan dan Responsiveness/kesigapan) tidak berpengaruh secara signifikan terhadap variabel dependen (Customer Satisfaction/ kepuasan pelanggan) sedangkan tiga variabel independen lainnya (Tangiblel bukti fisik, Assurance/jaminan, dan Empathy/perhatian) berpengaruh secara signifikan terhadap variabel depeden (Customer Satisfaction/kepuasan pelanggan). Dengan demikian, kesimpulannya gagal tolak $\mathrm{H}_{0}$ atau terima $\mathrm{H}_{0}$ yakni tidak ada pengaruh yang signifikan dari variabel Reliability dan Responsiveness terhadap variabel Customer Satisfaction sedangkan dari tiga variabel independen lainnya dapat ditarik kesimpulan tolak $\mathrm{H}_{0}$ atau terima $\mathrm{H}_{1}$ yakni ada pengaruh yang signifikan dari variabel Tangible, Assurance dan Empathy terhadap variabel Customer Satisfaction.

\section{DAFTAR PUSTAKA}

Sunyoto, Danang. (2009). Analisis Regresi dan Uji Hipotesis. Yogyakarta: Media Presindo.

Natawiria, Asep Suryana dan Riduwan. (2010). Statistika Bisnis. Bandung: Alfabeta.

Sugiyono. (2011). Statistika untuk Penelitian. Bandung: Alfabeta.

Rahayu, Sri. (2005). SPSS Versi 12.00 dalam Riset Pemasaran. Bandung: Alfabeta.

Pramesti, Wara \& Hartanto Sunardi. (2008). Statistika. Surabaya: Universitas PGRI Adibuana.

Scott, Dru. (2005). Customer Satisfaction, Cara Praktis Membangun Hubungan yang Menguntungkan dengan Pelanggan. Jakarta: PPM.

Arikunto, S. 2002. Prosedur Penelitian Suatu Pendekatan Praktik. Jakarta: Rineka Cipta.

Sujana. 2005. Metode Statistika. Bandung: Tartiso Bandung J1. Guntur No. 20

Simamora, Bilson. 2008. Panduan Riset Perilaku Konsumen, cetakan ketiga. Jakarta : PT. Gramedia Pustaka Utama,

Umar, Husein. 2003. Metode Riset Perilaku Konsumen Jasa. Jakarta: Ghalia Indonesia.

Arif, Andrian. 2011. Analisis Faktor yang Mempengaruhi Kepuasan Pelanggan PDAM Kota Gresik (Studi Kasus pada Masyarakat Kecamatan Gresik). Skripsi yang Tidak dipublikaikan ITS. 